\title{
Clinical Epidemiological Profile and Warning Signs of Dengue
}

Carolina Mariano Pompeo1, Marisa Dias Rolan Loureiro', Maria Gorette dos Reis ${ }^{1}$, Mercy da Costa Souza1, Isabelle Campos de Azevedo², Marcos Antonio Ferreira Júnior ${ }^{2}$

\section{Abstract}

Dengue is an arbovirus transmitted to human beings by the Aedes aegypti mosquito, characterized as a systemic viral infection of rapid geographical expansion and today, it a major global infectious problem with the potential risk of death for the individuals affected.

Objective: To describe the clinical and epidemiological profile and the most frequent and relevant warning signs of confirmed dengue cases occurred in Campo Grande, the capital of Mato Grosso do Sul (MS), Midwestern Brazil, during 2013 epidemic.

Method: This is a descriptive, analytical, cross-sectional and retrospective study conducted through analysis of patients' records treated at two public hospitals of reference for treatment of infectious and parasitic diseases (IPD) in the city of Campo Grande/MS, Brazil, during an epidemic in 2013.

Results: There were 91 confirmed cases of dengue analyzed; 86 of them met the criteria for the diagnosis of dengue with warning signs (DCWS) and five as severe dengue (SD). There was a predominance of females with $60 \%$ for cases of DCWA and $64 \%$ for SD. The age ranged from $42.65( \pm 2.22)$ for cases of DCWS and $60.40( \pm 6.98)$ years old for cases of SD. The Warning Signs associated with worsening of the disease were abrupt decreasing in platelets, dyspnea, hypothermia, confusion and psychomotor agitation. Three of the five cases of SD died (60\%).

Conclusion: The epidemiological situation of dengue in the city of Campo Grande/MS is configured as a public health problem. It is emphasized the importance of developing measures to control and combat of the disease, as well as entomological, sanitary and health surveillance become indispensable.

1 Biological and Health Sciences Center, Federal University of Mato Grosso do Sul, Campo Grande/MS, Brazil.

2 Department of Nursing, Health Science Center, Federal University of Rio Grande do Norte, Natal/RN, Brazil.

\section{Contact information:}

\section{Marcos Antonio Ferreira Júnior}

Address: Universidade Federal do Rio Grande do Norte, Centro de Ciências da Saúde, Departamento de Enfermagem. Avenida Salgado Filho, S/N, Lagoa Nova, Natal, RN, Brasil. CEP: 59078970.

झ marcos_nurse@hotmail.com
Keywords
Dengue; Severe Dengue; Epidemiology; Tertiary Health Care; Infectology. 


\section{Introduction}

Dengue is an arbovirus transmitted to human beings by the Aedes aegypti mosquito having four circulating and described serotypes [1]. The disease is characterized as a systemic viral infection that spreads rapidly and emerges as an important infectious disease in the current world, considered as a risk of death for some of the affected individuals. According to the World Health Organization (WHO), the incidence of dengue cases has increased exponentially in the last 50 years due primarily to the geographic expansion to new countries. It is estimated to occur 390 million of these infections annually, and only 96 million are symptomatic [24].

Currently, dengue fever is the most prevalent arbovirus in the world, and it is estimated that 3.6 billion people live in endemic countries with about $40 \%$ of the population at risk $[5,6]$. In Brazil, there is a reference to the disease since the nineteenth century, with epidemics reports in 1923, in Niterói city, Rio de Janeiro and 1946 in the city of São Paulo, both located in the southeastern region of Brazil, but without laboratory confirmation [7].

The first epidemic with clinical and laboratory documentation occurred in the northern Brazil between 1981 and 1982 in the city of Boa Vista, Roraima state, caused by serotypes 1 (DENV1) and 4 (DENV4). In the early 1990s, it was observed the circulation of serotype 2 (DENV 2) in the state of Rio de Janeiro with a significant increase of cases of the disease. Ten years later, in 2002, the circulation of serotype 3 (DENV 3) was first identified in the states of Rio de Janeiro and Roraima, respectively, which resulted in higher incidence of the disease ever recorded so far [8]. In 2010, the situation became even worse with the reintroduction of DENV 4 in the city of Boa Vista, Roraima state [9].

Since then, dengue is considered one of the most important infectious diseases mainly due to its high morbidity and mortality. In 2015, Brazil notified
$1,649,008$ cases of dengue to the Pan American Health Organization (PAHO) and in the first half of $2016,1,130,316$ cases of the disease have been reported $[10,11]$.

In the state of Mato Grosso do Sul, Midwest region of Brazil, there was a total of 44,523 cases in 2015 reported to the State Department of Health $(\mathrm{SDH})$, of which 12,955 cases occurred in the state capital, Campo Grande [12]. In the first half of 2016, 56,666 cases were reported, 27,382 of them in the state capital. [13]

Dengue has a very wide clinical spectrum ranging from the oligosymptomatic forms to severe hemorrhage and shock, and it may lead to death [3]. Furthermore, Aedes aegypti transmits two other diseases also considered high morbidity and mortality, such as Chikungunya fever and Zika.

In Brazil, 17,683 cases of Chikungunya fever were reported to PAHO in 2015, 560 of them were confirmed, and three deaths were reported. Currently, such arbovirus is present in 55 countries, including the Americas. [14] In December 2015, PAHO issued a warning to countries of the Americas to the attention to the neurological and congenital anomalies related to the Zika virus, which showed a significant increase in about 20 times the number of cases of microcephaly in live births since 2000, and the first serologic confirmation of Zika virus presence in the amniotic fluid of pregnant women in Brazil occurred in 2015 [15-19].

In January 2016, a new warning about Zika was published, in which 18 countries and territories have reported cases of this disease. Among them, Brazil already had cases in 18 states, mainly in the Northeast region [20].

In 2009, the WHO already presupposed the need for a differential diagnosis for diseases transmitted by Aedes aegypti and the potential risk of dengue worsening. Based on a multicenter study (Dengue Control - DENCO) a simplified classification was proposed, performed by easily accessible clinical and laboratory tests $[21,22]$. 
In this simplified classification, dengue cases are divided into two categories of severity. In the first category, the dengue is subdivided into "dengue without warning signs (DWWS) and dengue with warning signs (DCWS)". The second category is the "severe dengue (SD)". The warning signs are among the guiding patient care with dengue picture. Most of the time, the clinical and laboratory signs are plasma loss predictors and imminent shock, indicated by clinical deterioration and progression to severity. The correct management of patients depends on early recognition of signs and rapid initiation of therapy, which can be decisive for the outcome of the picture [4].

Recognizing the warning signs of worsening dengue is a step towards the systematization of assistance that can contribute positively to the success in reducing morbidity and mortality and the negative impacts caused by the disease in the society. In this perspective, the objective of this study is to describe the clinical and epidemiological profile and the most frequent and relevant warning signs of confirmed cases of dengue occurred in Campo Grande, the capital of Mato Grosso do Sul, Midwestern Brazil during 2013 epidemic.

\section{Method}

This is a descriptive and analytical, cross-sectional and retrospective study conducted through the analysis of patients' records treated at two public hospitals of reference for treatment of infectious and parasitic diseases (IPD) in the city of Campo Grande, capital of Mato Grosso South/MS, Midwestern Brazil, who had serologic or clinical-epidemiological confirmation of dengue by the Municipal Public Health (SESAU) during 2013 epidemic.

There were 170 medical records of patients with suspected cases of dengue analyzed, of which 91 were the universe of this research because they were confirmed cases. Data of patients' records that were clinical or laboratory proved were included, that after the WHO Protocol by 2009 reclassification met criteria for the diagnosis of dengue with warning signs (DCWS) and SD. The records that were incomplete and were not available for consultation were excluded.

The variables extracted from medical records were gender, age, dengue confirmation method, the reason for referral, warning signs and outcome. The evaluation of the association between the type of dengue and the variables studied in this research was performed using the chi-square test. The comparison between DCWS and SD about quantitative variables was performed using the t-Student test. The other results were presented as descriptive statistics in tables. Statistical analysis was performed using the statistical program Statistic Package for Social Sciences (SPSS), version 22.0, and the significance level was 0.05 .

This study was approved by the Ethics Committee on Human Beings Research linked to the Federal University of Mato Grosso do Sul, in Opinion $N^{\circ}$ 867,375, on November 2, 2014, in compliance with regulatory standards for research in human beings, according to CNS/MS Resolution N466/2012 [23].

\section{Results}

According to Table 1, there were 91 cases of dengue identified and treated in two reference hospitals to IPD in the state; 86 of them (94.5\%) presented the criteria for DCWS and five (5.5\%) for SD since they had the same characteristics described in WHO protocol [4].

Of the total cases, 78 (85.7\%) were referrals from Basic Health Units (BHU) after the first visit, when the reasons were clinical worsening in 27 cases (34.6\%), laboratory worsening in 20 (25.6\%) and both in 31 cases (39.8\%). The remaining cases spontaneously sought the hospital, of which 11 (84.6\%) sought the service by clinical worsening and two (15.4\%) by laboratory and clinical worsening. More than half of treated cases of DCWS were female (60\%), espe- 
cially also for cases of SD (60\%). Ages ranged from $42.65 \pm 2.22$ of DCWS cases and $60.40( \pm 6.98)$ years old for SD cases. (Table 1)

The warning signs DCWS cases were nausea and vomiting (52.3\%), persistent abdominal pain (48.8\%), blood concentration (30.1\%), sudden decrease in platelets $(<20,000)(12.8 \%)$, respiratory distress $(10.5 \%)$, syncope (3.5\%), decreased urine

Table 1. Distribution of cases of dengue ${ }^{1}$ by classification, according to the clinical and epidemiological characteristics. Campo Grande/ MS, Brazil, in 2016 ( $n=91)$.

\begin{tabular}{|c|c|c|c|c|c|}
\hline \multirow{4}{*}{ Variables } & \multicolumn{4}{|c|}{ Dengue } & \multirow{4}{*}{$P^{4}$} \\
\hline & \multirow{2}{*}{\multicolumn{2}{|c|}{$\frac{\text { DCWS }^{2}}{(n=86)}$}} & \multirow{2}{*}{\multicolumn{2}{|c|}{$\frac{S^{3}}{(n=05)}$}} & \\
\hline & & & & & \\
\hline & $n$ & $\%$ & $n$ & $\%$ & \\
\hline \multicolumn{6}{|l|}{ Gender } \\
\hline Female & 55 & 64.0 & 03 & 60.0 & \multirow{2}{*}{0.858} \\
\hline Male & 31 & 36.0 & 02 & 40.0 & \\
\hline Age & \multicolumn{2}{|c|}{$42.65 \pm 2.22$} & \multicolumn{2}{|c|}{$60.40 \pm 6.98$} & 0.060 \\
\hline \multicolumn{6}{|l|}{ Confirmation } \\
\hline Clinical Epidemiological & 47 & 54.7 & 02 & 40.0 & \multirow[t]{2}{*}{0.523} \\
\hline Laboratory & 39 & 45.3 & 03 & 60.0 & \\
\hline \multicolumn{6}{|l|}{ Reasons for referral } \\
\hline Clinical worsening & 37 & 43.0 & 01 & 20.0 & \multirow{3}{*}{0.103} \\
\hline Laborator y worsening & 20 & 23.3 & 00 & 00.0 & \\
\hline $\begin{array}{l}\text { Clinical and laboratory } \\
\text { worsening }\end{array}$ & 29 & 33.7 & 04 & 80.0 & \\
\hline \multicolumn{6}{|l|}{ Outcome } \\
\hline Hospital discharge & 82 & 95.3 & 02 & 40.0 & \multirow{4}{*}{$<0.001$} \\
\hline Evasion & 02 & 2.3 & 00 & 0.0 & \\
\hline Death & 00 & 0.0 & 03 & 60.0 & \\
\hline $\begin{array}{l}\text { Transfer to another } \\
\text { hospital }\end{array}$ & 02 & 2.3 & 00 & 0.0 & \\
\hline \multicolumn{6}{|l|}{ Referral } \\
\hline No & 13 & 15.1 & 00 & 0.0 & \multirow{2}{*}{0.348} \\
\hline Yes & 73 & 84.9 & 05 & 100.0 & \\
\hline
\end{tabular}

output (3.5\%), altered level of consciousness with confusion (1.2\%) and psychomotor agitation (1.2\%). The hematocrit value was $39.57 \%$ ( \pm 0.65$)$.

For of SD cases, the Warning Signs were intense and persistent abdominal pain (80\%) with respiratory distress and abrupt decrease in platelets and hepatomegaly (60\%), hypothermia, confusion and agitation (40\%), nausea, persistent vomiting, blood concentration and decreased urine output (20\%).

\section{(Table 2)}

Among the warning signs defined by the Ministry Health Protocol of Brazil (2013), five were strongly associated with worsening of the disease, such as the sharp decrease in platelets $(p=0.004)$, respiratory distress ( $p=0.001)$ and hypothermia and altered level of consciousness (confusion and psychomotor agitation) $(p<0.001)$.

Table 2. Distribution of cases of dengue ${ }^{1}$ by the classification and warning signs², Campo Grande/MS, Brazil, in 2016 ( $n=91)$.

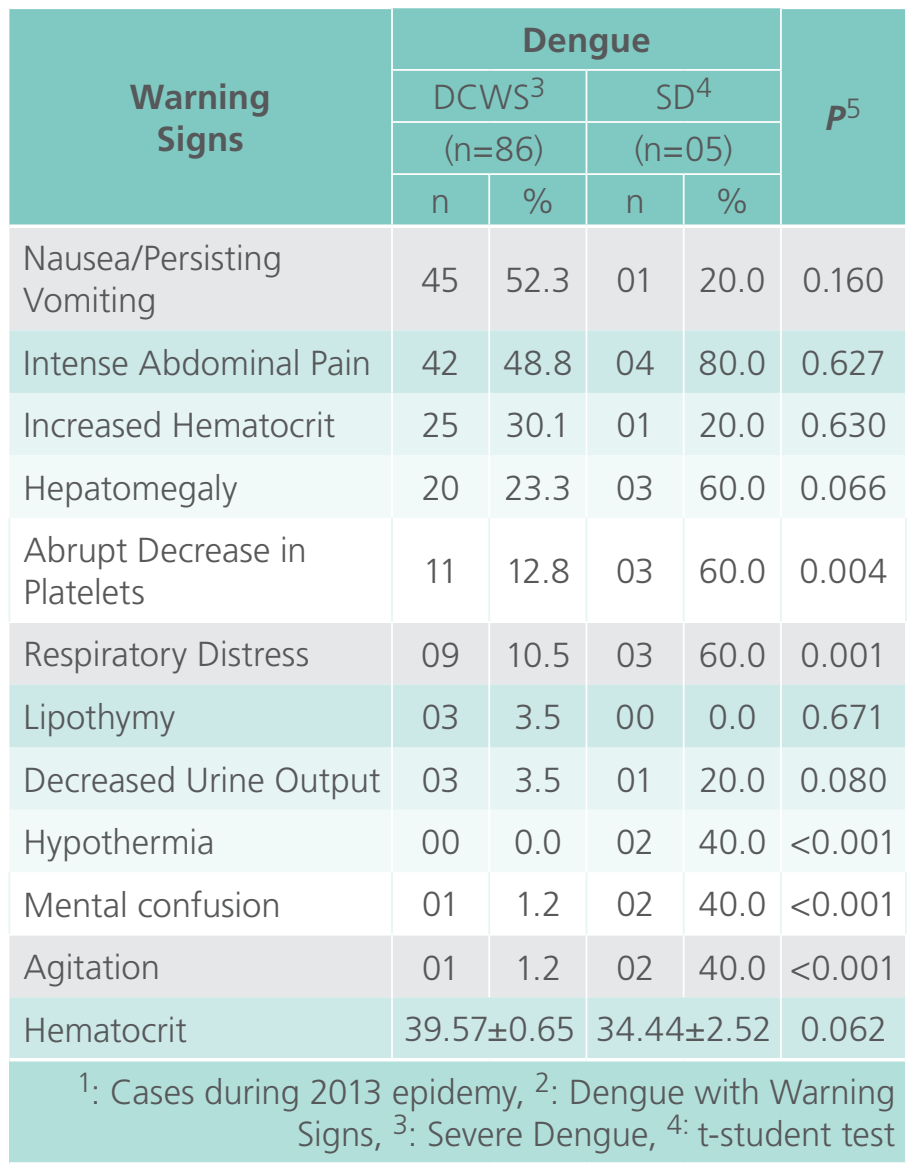




\section{Discussion}

According to the epidemiological variables, there was a predominance of females in both classifications of dengue cases, in a same trend detected in a study conducted by the Notifiable Diseases Information System (SINAN) and Hospital Information System $(\mathrm{SIH})$ who analyzed the distribution of dengue cases recorded between 2002 and 2010, when the female totaled more than half of the reported cases [24].

Similar data were found in a study conducted in 2009 in the same geographical area, in which $52.6 \%$ of cases were female, which also prevailed in the most severe cases of the disease, with $52.6 \%$ of cases of Dengue With Complications (DWC) and 54.4 cases of Hemorrhagic Fever Dengue (DHF) and Shock Syndrome Dengue (SSD) [25]. In another study conducted in Goiânia, the state capital of Goiás, also located in the Midwest region of Brazil, 52.7\% of cases occurred among women [26], which may be associated with the possibility of their greater permanence at home and the urban characteristics vector [27].

The predominant age group for cases of DCWS was $42.65( \pm 2.22)$ and 60.40 years old ( \pm 6.98) for cases of SD. Over $50 \%$ of cases of DCWS had clinical and epidemiological confirmation, different from SD cases, for which the laboratory confirmation was performed in $60 \%$ of cases. This total of laboratory confirmation for cases of DCWS is above the stipulated by the Ministry of Health of Brazil that for the epidemic period allows the clinical and epidemiological confirmation of the disease in about $10 \%$ cases of dengue. However, this same protocol points out that for severe cases of the disease, risk groups or situations they should receive laboratory confirmation in full [28].

Regarding the outcome, $60 \%$ cases of SD died, and the others were discharged after clinical improvement. A study in the city of Aracaju, the capital of Sergipe state, located in the northeastern region of Brazil, with 10,165 confirmed cases of dengue, showed that the 18 deaths were all classified as the most severe forms of the disease [29].

Regarding the warning signs, a study in Singapore found that when the patient has any of these signs, the chances of developing into the hemorrhagic form of the disease are $87 \%$, and the chances of progression to more severe disease are $96 \%$ [30]. A significant association between one or more warning signs and the worsening of the disease was also found in a study conducted in Brazil between 2000 and 2005 [31].

An assessment of deaths from dengue seen at a University Medical Center in Malaysia between 2006 and 2007, found that a large number of patients who died they had some warning sign to the worsening dengue. These signs and comorbidities may have been the factors that contributed to the worsening of the condition. The most common warning signs of this study were the sharp decrease in platelets, intense and persistent abdominal pain, blood concentration, most notably respiratory distress, hypothermia and neurological manifestations confusion and agitation. [32]

Although in this study the abdominal pain had not significant association presented with the worsening dengue, this was found in $48.8 \%$ of cases of DCWS and $80 \%$ of cases of SD. Abdominal pain is configured as an important predictor of deterioration with a three times increasing the severity of the disease [33].

Thrombocytopenia was found as a marker of dengue severity in a study by Robert Children Hospital in Santo Domingo in the Dominican Republic, with 796 confirmed cases of dengue, of which 288 were classified as dengue, 290 as DCWS and 207 as SD. As a borderline statistical base, the platelet of $30,000 / \mathrm{mm}^{3}$ was used. However, there was a significant association with severe disease and mortality, even with the close platelet count to $58,000 /$ $\mathrm{mm}^{3}$ [34].

A study conducted by the Kaohsiung Chang Gung Memorial Hospital in Taiwan with 1,063 patients, 
found that 1,008 were classified as non-severe dengue, 55 as SD and 23 evolved with shock. The results also showed a significant association between severe thrombocytopenia and the worsening of the disease, in which the platelet count was 50,000/ $\mathrm{mm}^{3}$ [35].

A retrospective study conducted in Puerto Rico identified abdominal pain, persistent vomiting, sudden temperature change and the altered level of consciousness as the main warning signs [36]. These data corroborate findings of research conducted in Singapore, which related to abdominal pain, nausea and persistent vomiting present in half of the patients who died because of dengue [37].

In a study conducted in India with 198 patients, 186 of them survived, and 15 died. Of the total, $26(13.1 \%)$ had respiratory failure and in 15 that died, 11 (91.7\%) had acute respiratory distress, a significant result of research with $p<0.005$. As for the sensory change in the total number of patients, five $(2.5 \%)$ had this picture, and four who died, (33.3\%) had some altered level of consciousness $(p<0.005)$. By the results, it was possible to realize the significant relationship between these changes and the poor prognosis and worsening of symptoms [38].

On hypothermia, a retrospective study of 390 patients with dengue diagnostic found that of 10 patients who died, hypothermia was present in two (20\%) cases, and this symptom was not observed in any of the survivors. Thus, it may be possible to infer that hypothermia can be considered as one of the indicators of the worsening of the disease [39].

\section{Conclusion}

It is concluded that among patients with symptoms of DCWS, more than half are female, most were referred by basic health units and warning signs most frequently diagnosed were nausea and vomiting, persistent abdominal pain and blood concentration.
Among those with SDG, there was also a prevalence of females and the warning signs found were intense and persistent abdominal pain, respiratory distress and sudden decrease of platelets.

It can be seen that the epidemiological situation of dengue in the city of Campo Grande/MS, Brazil is configured as a public health problem. It is emphasized the importance of developing measures to control and combat the disease, as well as entomological, sanitary and health surveillance become essential, given that in the absence of effective vaccine against the disease, vector control and eliminating their breeding sites are configured as the only possible way to combat the spread of the disease. Thus, also, to building public policies designed and implemented to this end, encouraging the community participation needs to be permanent, and the results or answers expectations should be considered in the medium and long term.

\section{References}

1. Viana DV, Ignotti E. The occurrence of dengue and weather changes in Brazil: A syste matic review. Rev Bras Epidemiol. 2013; 16(2): 240-56. Available from: http://www.scielo.br/pdf/ rbepid/v16n2/en 1415-790X-rbepid-16-02-00240.pdf

2. Bhatt S, Gething PW, Brady OJ, Messina JP, Farlow AW, Moyes $\mathrm{CL}$, et al. The global distribution and burden of dengue. Nature. 2013; Volume: 496: Pages: 504-7. Available from: http://www. nature.com/nature/journal/v496/n7446/full/nature12060.html

3. Simmons CP, Farrar JJ, Van Vinh Chau N, Wills B. Dengue. N. Engl. J. Med. 2012; 366: 1423-32. Available From http://www. nejm.org/doi/full/10.1056/NEJMra1110265

4. World Health Organization. Dengue: Guidelines for Diagnosis, Treatment, Prevention and Control. Genebra: WHO; 2009. Available from: http://www.who.int/tdr/publications/ documents/dengue-diagnosis.pdf

5. Harrington J, Kroeger A, Runge-Razinger S, O'Dempsey $T$. Detecting and Responding to a Dengue Outbreak: Evaluation of Existing Strategies in Country Outbreak Response Planning. Journal of Tropical Medicine. 2013; 9: 1-10. Available from: http://www.hindawi.com/journals/jtm/2013/756832/

6. Viero DV, Ignotti $V$. The occurrence of dengue and weather changes in Brazil: A systematic review. Rev. bras. epidemiol. 2013; 16(2): 240-56. Available from: http://www.scielo.br/pdf/ rbepid/v16n2/en 1415-790X-rbepid-16-02-00240.pdf 
7. Brasil. Ministério da Saúde. Secretaria de Vigilância em Saúde. Guia de Vigilância em Saúde. Brasília: Ministério da Saúde; 2014. Available from: http://portalsaude.saude.gov.br/images/ pdf/2014/novembro/27/guia-vigilancia-saude-linkado-27-11-14. pdf

8. Brasil. Ministério da Saúde. Secretaria de Vigilância em Saúde. Departamento de Vigilância Epidemiológica. Diretrizes Nacionais para a Prevenção e Controle de Epidemias de Dengue. Brasília: Ministério da Saúde; 2009. Available from: http://bvsms. saude.gov.br/bvs/publicacoes/diretrizes nacionais prevencao controle dengue.pdf

9. Brasil. Fundação Nacional de Saúde. Coordenação Geral de Planejamento e avaliação. Relatório de gestão 2010. Brasília: Fundação Nacional de Saúde; 2011. Available from: http:// www.funasa.gov.br/site/wp-content/uploads/2011/10/ relatorio 2010.pdf

10. Pan American Health Association. Number of Reported Cases of Dengue and Severe Dengue (SD) in the Americas, by Country. Epidemiological Week/EW 52. 2015. Available from: http:// www.paho.org/hq/index.php?option=com topics\&view=reada Il\&cid=3273\&ltemid=40734\&lang=en

11. Pan American Health Association. Number of Reported Cases of Dengue and Severe Dengue (SD) in the Americas, by Country. Epidemiological Week/EW 21. 2016. Available from: http:// www.paho.org/hq/index.php?option=com topics\&view $=$ articl e\&id=1\&ltemid $=40734$

12. Secretaria de Estado de Saúde de Mato Grosso do Sul. Boletim Epidemiológico Dengue. Serviço de Vigilância Epidemiológica. 2015; (52). Available from: http://www.saude.ms.gov.br/geral/ vigilancia-saude/vigilancia-epidemiologica/controle-de-vetores/ dengue/

13. Secretaria de Estado de Saúde de Mato Grosso do Sul. Boletim Epidemiológico Dengue. Boletim Epidemiológico Dengue. Serviço de Vigilância Epidemiológica. 2016; (21). Available from: $\quad$ http://www.saude.ms.gov.br/wp-content/uploads/ sites/88/2016/06/BOLETIM-EPIDEMIOL\%C3\%93GICODENGUE-1.pdf

14. Pan American Health Organization. Number of Reported Cases of Chikungunya Fever in the Americas by country or territory. Epidemiological Week/EW 52. 2015. http://www.paho.org/hq/ index.php?option $=$ com docman\&task=doc view\&Itemid $=270$ \&gid $=33091$ \&lang $=e n$

15. Zanluca C, Melo VCA, Mosimann ALP, Santos GIV, Santos CND, Luz K. First report of autochthonous transmission of Zika virus in Brazil. Mem Inst Oswaldo Cruz. 2015; 110(4): 569-72. Available from: http://dx.doi.org/10.1590/0074-02760150192

16. World Health Organization. Zika virus outbreaks in the Americas. Wkly Epidemiol Rec. 2015; 90(45): 609-10. Available from: http://www.who.int/wer/2015/wer9045.pdf?ua=1
17. Schuler-Faccini L, Ribeiro EM, Feitosa IML, Horovitz DDG, Cavalcanti DP, Pessoa A, et al. Possible Association Between Zika Virus Infection and Microcephaly - Brazil, 2015. MMWR Morb Mortal Wkly Rep. 2016; 65(3): 59-62. Available from: http://dx.doi.org/10.15585/mmwr.mm6503e2

18. Minamisava R, Salge AKM, Castral TC, Souza SMB, Souza RRG, Sousa MC. Zika virus epidemic: the newest international emergency. Rev. Eletr. Enf. 2016; 18: 1-3. Available from: https:// revistas.ufg.br/fen/article/view/39890/21132

19. Salge AKM, Castral TC, Sousa MC, Souza RRG, Minamisava $R$, Souza SMB. Zika virus infection during pregnancy and microcephaly in newborns: an integrative literature review. Rev. Eletr. Enf. 2016; 18: 1-14. Available from: https://revistas.ufg.br/ fen/article/view/39888/21133

20. Pan American Health Organization. Epidemiological alert: Neurological syndrome, congenital malformation, and Zika virus infection. 2016. Available from: http://www.paho.org/hq/index. php?option $=$ com docman\&task $=$ doc view $\&$ ltemid $=270 \&$ gid $=$ 32879\&lang=en

21. Orsini M, Freitas MRG, Nascimento OJM, Catharino MAS, Mello MP, Reis CHM, et al. Guillain-Barré Syndrome after Dengueilnfection: Case Report. Rev Neurociências. 2010; 18(1): 24-7. Available from: http://www.revistaneurociencias.com.br/ edicoes/2010/RN1801/280\%20relato\%20de\%20caso.pdf

22. Verdeal JCR, Costa Filho R, Vanzillotta C, Macedo GL, Bozza $F A$, Toscato $L$, et al. Guidelines for the management of patients with severe forms of dengue. Rev Bras Ter Intensiva. 2011; 23(2): 125-33. Available from: http://www.scielo.br/pdf/rbti/v23n2/ en a04v23n2.pdf

23. Brasil. Ministério da Saúde. Conselho Nacional de Saúde. Resolução n 466/2012 de 12 de dezembro de 2012. Aprova as diretrizes e normas regulamentadoras de pesquisa envolvendo seres humanos. Brasília: CNS; 2012. Available from: http://bvsms. saude.gov.br/bvs/saudelegis/cns/2013/res0466 $12 \quad 122012$. $\underline{\mathrm{html}}$

24. Siqueira Júnior JB, Vinhal LC, Said RFB, Hoffmann JL, Martins J, Barbiratto SB, et al. Dengue no Brasil: tendências e mudanças na epidemiologia, com ênfase nas epidemias de 2008 e 2010. In: Brasil. Saúde Brasil 2010: uma análise da situação de saúde e de evidências selecionadas de impacto de ações de vigilância em saúde. 1. ed. Brasília: Ministério da Saúde, 2011. p. 157169. Available from: http://bvsms.saude.gov.br/bvs/publicacoes/ saude brasil 2010.pdf

25. Pinto DPSR, Gaetti-Jardim EC, Loureiro MDR, Cunha RV, Quintanilha ACF, Ferreira Júnior MA. Aspectos epidemiológicos e clínicos dos casos de internação hospitalar durante epidemia de dengue. Rev enferm UFPE on line. 2014; 8(6): 1568-76. Availabe from: http://www.revista.ufpe.br/revistaenfermagem/ index.php/revista/article/viewFile/5787/pdf 5246 
26. Fantinati $A M M$, Santos $A C A$, Inumaru SS, Valerio VT, Fantinati MS. Perfil epidemiológico e demográfico dos casos de dengue na região central de Goiânia - Goiás: de 2008 a março de 2013. Tempus - Actas de Saúde Coletiva. 2013; 7(2): 107-19. Available from: $\quad$ http://www.tempusactas.unb.br/index.php/tempus/ article/view/1347/1150

27. Guollo DSO, Silva RC, Peluzio JM, Carmo Filho JR. Aspectos epidemiológicos da dengue em Cuiabá-MT entre 2007 e 2011. Estudos. 2015; 42(4): 503-16. Available from: http://seer.ucg.br/ index.php/estudos/article/download/4368/2503

28. Brasil. Ministério da Saúde. Secretaria de Vigilância em Saúde. Departamento de vigilância epidemiológica. Dengue: diagnóstico e manejo clínico: adulto e criança. Brasília: Ministério da Saúde; 2013. Available from: http://bvsms.saude.gov.br/bvs/ publicacoes/dengue diagnostico manejo clinico adulto.pdf

29. Cunha PEL, Bohland AK. Dengue: descrevendo a epidemia em Aracaju, Sergipe, Brasil, 2008. Rev bras med fam comunidade. 2012; 7(25): 247-54. Available from: https://rbmfc.org.br/rbmfc/ article/view/402

30. Thein TL, Gan VC, Lye DC, Yung CF, Leo YS. Utilities and Limitations of the World Health Organization 2009 Warning Signs for Adult Dengue Severity. PLoS negl Trop Dis. 2013; 7(1): 1-6. Available from: http://www.ncbi.nlm.nih.gov/pmc/articles/ PMC3547865/

31. Moraes GH, Duarte EF, Duarte EC. Determinants of Mortality from Severe Dengue in Brazil: A Population-Based Case-Control Study. Am J Trop Med Hyg. 2013; 88(4): 670-6. Available from: http://www.ncbi.n/m.nih.gov/pmc/articles/PMC3617850/

32. San SS, Omar SF, Teoh BT, Abd-Jamil J, Abubakar S. Review of Dengue Hemorrhagic Fever Fatal Cases Seen Among Adults: A Retrospective Study. PLoS negl Trop Dis. 2013; 7(5): 1-7. Available from: http://www.ncbi.nlm.nih.gov/pmc/articles/PMC3642057/

33. Alexander N, Balmaseda A, Coelho IC, Dimaano E, Hien TT, Hung NT, et al. Multicentre prospective study on dengue classification in four South-east Asian and three Latin American countries, Trop Med Int Health. 2011; 16(8): 936-48. Available from: http:// onlinelibrary.wiley.com/doi/10.1111/j.1365-3156.2011.02793.x/full

34. Lora AJM, Fernandez J, Morales A, Soto $Y$, Feris-Iglesias J, Brito MO. Disease severity and mortality caused by dengue in a dominican pediatric population. Am J Trop Med Hyg. 2014; 90(1): 169-72. Available from: http://www.ncbi.nlm.nih.gov/ pmc/articles/PMC3886416/
35. Lee IK, Liu JW. The early clinical features and predictors of severe dengue and dengue shock syndrome in adult patients. Journal of Microbiology, Immunology and Infection. 2015; 48(2). Available from: http://www.e-jmii.com/article/S16841182(15)00454-5/pdf

36. Rigau-Pérez JG. Severe dengue: the need for new case definitions. Lancet Infect Dis. 2006; 6(5): 297-302. Available from: $\quad$ http://www.thelancet.com/journals/laninf/article/ PIIS1473-3099(06)70465-0/fulltext

37. Ong A, Sandar M, Chen MI, Sin LY. Fatal dengue hemorrhagic fever in adults during a dengue epidemic in Singapore. Int J Infect Dis. 2007; 11(3): 263-7. Available from: http://www. iiidonline.com/article/S1201-9712(06)00122-6/fulltext

38. Juneja $D$, Nasa $P$, Singh $O$, Javeri $Y$, Uniyal B, Dang R. Clinical profile, intensive care unit course, and outcome of patients admitted in intensive care unit with dengue. J Crit Care. 2011; 26(5): 449-52. Available from: http://www.jccjournal.org/ article/S0883-9441(11)00209-7/fulltext

39. Lee IK, Liu JW, Yang KD. Fatal dengue hemorrhagic fever in adults: emphasizing the evolutionary pre-fatal clinical and laboratory manifestations. PLoS Negl Trop Dis. 2012; 6(2): 1-8. Availble from: http://www.ncbi.nlm.nih.gov/pmc/articles/ PMC3283557/

\section{Publish in International Archives of Medicine}

International Archives of Medicine is an open access journal publishing articles encompassing all aspects of medical science and clinical practice. IAM is considered a megajournal with independent sections on all areas of medicine. IAM is a really international journal with authors and board members from all around the world. The journal is widely indexed and classified Q2 in category Medicine. 